\title{
ANALYSIS OF AGRARIAN SECTOR RESOURCE PROVIDING IN UKRAINE
}

\author{
Iryna BEZPIATA ${ }^{1}$ \\ Mykolaiv National Agrarian University, Ukraine
}

\begin{abstract}
The aim of this article is an analysis of material well-being level in agrarian sector of economy by productive resources (by land, labour, hardware) providing with that provides efficiency of economic activity and ground of basic directions of the rational bringing in and use of resource potential of agrarian sector of economy in Ukraine in market conditions. Research methodology consists in the use of statistical and economic research methods for analysis of productive resources using modern state of agriculture for period from 2010 to 2014 years. Research results show that the resource providing agrarian sector development can be defined as totality of certain types of resources (land, technological, labour, financial) and sources of their forming, directly participating in the processes of agrarian sector economies development that can be mobilized with the purpose of providing the scale using of their potential possibilities and transition of agriculture to the qualitatively new state. Analysis of the modern state of material well-being of agrarian sector resources of economy in Ukraine is unsatisfactory and with every year gets worse. To overcome this problem agricultural commodity producers are unable only by themselves. For the improvement of the economic state of agrarian sector of economy in whole country and regional state support of home agricultural producer, stimulation of his activity is needed. And first of all the self-weighted investment policy of the state should become such measures in the agrarian sector of economy that will allow bringing in of greater amount of investment resources for the improvement of technical equipment at agricultural enterprises, development of production co-operation and products sale, introduction of personnel management modern methodology, increase in labour activity level in agrarian sector, realization of the permanent updating and increase in products quality control, etc. Practical value. Got results in the process of research can be drawn on in practical activity of agricultural commodity producers, management organs at regional and national level on increasing of resource potential using efficiency in agrarian sector of economy. Value/originality. Research results allow defining basic directions for increasing of resource potential using efficiency in agrarian sector of economy. One of terms of efficiency introduction, competitive and high-performance agricultural production is investment activity that is sent to financing of the projects and programs, related to development of agrarian economy sector. Investment activity is based on investment policy of the state, clear legislative field, set priorities and directions and sent to forming of effective management mechanism by investments, creation of economically advantageous terms that would stimulate stock accumulations and its effective use, taking into account realities and specific of agrarian economy sector.
\end{abstract}

Key words: agricultural sector, land resources, labour resources, technical and technological providing of agrarian sector, plant-grower, stock-raising.

JEL Classification: Q15, R34, O13

\section{Introduction}

Agrarian sector - is one of basic industries of national economy from which efficiency of functioning are depended state food safety as well as effective work of contiguous industries, their competitiveness and development of the state. Modern economic position of most agricultural commodity producers that provide creation of value added to a full degree, and thus, the economic value of the state, gives an opportunity to carry out only a simple recreation. The indicated is predetermined by many factors among that in particular: the ineffective use of available assets and resources; use of underproductive and ineffective technologies and facilities; absence of the clear, systematized protectionism of public policy in part of investment of capital public investments in development and modernisations of industry, introduction of development of scientific and technical progress and others like that. One of terms of introduction of effective, competitive and high-performance agricultural production there is investment activity (Tatarenko, 2012).

\footnotetext{
Corresponding author:

${ }^{1}$ Department of Economy of Companies, Mykolaiv National Agrarian University.

E-mail: bezpyata@gmail.com
} 


\section{Basic constituents}

\section{of resource potential in agrarian sector}

Ukrainian agricultural resource potential is submitted by land, water, climate and biological resources. Land is essential one among all of them, which is the main production mode in agriculture. In recent decades the development of this sector is held basing on the maximal utilization of the production of land resources.

Ukraine owns considerable land resources. At the end of 2014 its land fund was 60,3 million hectare, or nearly 6\% of Europe. In particular, agricultural land in the structure of the country's land is $70,8 \%$, forests $-17,6 \%$, water $-4,0 \%$.

At the end of 2014 Ukraine had 41,5 million hectares of farmland. Over 27,5 million hectares of land were privatised. Over 7 million of citizens received land certificates (share), $96 \%$ of certificates were replaced by state acts on land private ownership. Entirely new land relations were formed, basing on the private ownership of land.

Based on established land lease, agricultural formations of market direction were created. In recent years, there is a reduction of arable land in farms and an increase in their farms and households (Lupenko, 2012). The area of arable land accounted for $26,7 \mathrm{mln}$. hectares in 2000, farms $1,1 \mathrm{mln}$. hectares and households $-4,4 \mathrm{mln}$. hectares. At the end of 2014 - under 19,3 mln. hectares, 3,9 mln. hectares and 11,8 mln. hectares accordingly.

The vast majority of agricultural producers do not adhere to scientifically based crop rotation and soilprotecting technologies. The right amount of organic and mineral fertilizers is not used for the cultivation of crops, leading to soil depletion, reduced fertility and increased degradation. Agricultural development of the soil exceeds environmental standards. According to the Government
Land Agency (table 1) the plowed farmland in Ukraine at the end of 2014 was $78 \%$, and in some areas - up to $90 \%$, which is dangerous, especially when there are large areas of eroded lands. Excessive tillage leads to an annual increase in eroded areas to 80-90 thousand hectares. The share of agricultural land, exposed to the harmful effects of water erosion, is more than $30 \%$, deflated soil occupies a half of the arable land. The ecological condition of large areas of agricultural land is the poor, particularly the area of acid soils occupies $10,4 \mathrm{mln}$. ha $(25,0 \%)$, saline (medium and largely) and 35 saline $-4,7 \mathrm{mln}$. ha $(11,3 \%)$, wetlands $3,9 \mathrm{mln}$. ha $(9,4 \%)$, stony $-5,4 \mathrm{mln}$. ha $(13,0 \%)$.

Efficient and ecologically safe use of bioclimatic potential and natural soil fertility is decisive strategic factor of the production of human activity in agriculture. The fertility of the land is easier to lose than to restore. Moreover, the last one takes a lot of effort, money, resources and time.

Also, an important prerequisite for the efficient use of land resources and compliance with agricultural technology is the optimal ratio of sectors of production (crop and livestock) in agricultural formations. It affects the selection of crop rotation, efficient use of land resources, overcome seasonality. Crop cultivation includes a large number of crops that combine four homogeneous groups: grains and legumes, technical, potatoes, and vegetable and melon, and forage crops. The structure acreage effects productivity, overall productivity of the land, the state and fodder for livestock development, and therefore determines the level of production of all agricultural producers.

The largest share of the acreage of Ukraine during the last 5 years is occupied by cereals $-50 \%$, the second come technical cultures $-30 \%$, including almost $20 \%$ are sunflower crops. The smallest share in the structure of

Table 1

Structure of agricultural areas of Ukraine

\begin{tabular}{|c|c|c|c|c|c|}
\hline Years & $\begin{array}{c}\text { Agricultural lands, } \\
\text { th. ha }\end{array}$ & $\begin{array}{c}\text { Including plough } \\
\text { land, th. ha }\end{array}$ & $\begin{array}{c}\text { \% for agricultural } \\
\text { lands }\end{array}$ & $\begin{array}{c}\text { Sowing areas of agricultural } \\
\text { cultures, th. ha }\end{array}$ & \% for plough-land \\
\hline 2010 & 41576,0 & 32476,5 & 78,11 & 26951,5 & 82,99 \\
\hline 2011 & 41557,6 & 32498,5 & 78,20 & 27670,5 & 85,14 \\
\hline 2012 & 41536,3 & 32518,4 & 78,29 & 27801,3 & 85,49 \\
\hline 2013 & 41525,8 & 32525,5 & 78,33 & 28329,3 & 87,10 \\
\hline 2014 & 41511,7 & 32531,1 & 78,37 & 27239,1 & 83,73 \\
\hline
\end{tabular}

Source: from data of GST of Ukraine

Table 2

Dynamics of agricultural cultures production in Ukraine, thousand tones

\begin{tabular}{|l|c|c|c|c|c|c|}
\hline \multirow{2}{*}{ Types of agricultural cultures } & \multicolumn{5}{c|}{ Years } \\
\cline { 2 - 7 } & 2010 & 2011 & 2012 & 2013 & 2014 & 2014 in \% to 2014 \\
\hline Grain and leguminous crops & 39270,9 & 56746,8 & 46216,2 & 63051,3 & 63859,3 & 162,61 \\
\hline Sugar beets (factory) & 13749,2 & 18740,5 & 18438,9 & 10789,4 & 15734,1 & 114,44 \\
\hline Sunflower & 6771,5 & 8670,5 & 8387,1 & 11050,5 & 10133,8 & 149,65 \\
\hline Beets & 1447,7 & 1412,4 & 1196,1 & 2335,3 & 2198,0 & 151,83 \\
\hline Potato & 18704,8 & 24247,7 & 23250,2 & 22258,6 & 23693,4 & 126,67 \\
\hline Vegetables & 8122,4 & 9832,9 & 10016,7 & 9872,6 & 9637,5 & 118,65 \\
\hline Garden-stuffs and berries & 1746,5 & 1896,3 & 2008,7 & 2295,3 & 1999,1 & 114,46 \\
\hline
\end{tabular}

Source: from data of GST of Ukraine 
sown areas of crops is occupied by fodder crops and each year this figure is reduced. These trends are agricultural producers' reaction to market demands and low regulation of the agro-food market in Ukraine.

Production of basic types of agricultural products given by volumes, in particular plant-growers, in Ukraine in the economies of all categories is driven to the table 2 .

Undertaken study of plant-grower development testifies that for the last five years the production of plantgrower goods increases gradually. During 2010-2014 the production of grain and leguminous crops increased to $62,61 \%$, sugar beets - to $14,44 \%$, sunflower - to $49,65 \%$, potato $-26,67 \%$, vegetables $-18,65 \%$.

In the pattern of grain production and leguminous crops in 2014 most part belongs to corn on grain $-44,63 \%$, wheat $-37,77 \%$ and barley $-14,46 \%$.

Due to stable domestic demand for grain of wheat, barley, corn, and also seed of sunflower, Ukraine continues to occupy leading positions in the world agricultural market. Ukraine supplies to the world market more than $15 \%$ of corn and over $10 \%$ of grain-growing, yielding after the export of agricultural production only to the USA (Zorya, 2015).

On results of 2014 the leader in grain-crops export is a corn, the volume of sale of which attained over $14,9 \mathrm{mln}$. tons, providing the first place among export cultures (Kernasyuk, 2015).

The level of population food providing is examined as a major factor and qualificatory criterion of standard of the social living of any country, viability of its economic pattern and political system. In the decision of this problem the special role belongs to the stock-raising.

A stock-raising is a complex of connected agriculture industries. It provides the population with feed (meat, milk, eggs), industry with the most valuable foods with raw material (skins, fur, wool, fuzz, feather), and plant-grower - with organic fertilizers. A stock-raising embraces the row of subindustries, basic among which are the cattle breeding, pig breeding, sheep breeding, poultry farming.

Without regard to favourable in Ukraine terms for development of stock-raising industry, production and consumption of products volumes calculating per one person dissatisfy the rational norms and are considerably low in comparison with other countries in the world.
Studying the basic tendencies of cattle and bird population indexes changing it follows in Ukraine, that in the last few years there is a trend to reduction in cattle population to $13,58 \%$ (from 4494,4 thousand herd in 2010 to 3884,0 thousand herd of cattle in 2014). Such types of cattle have an analogical tendency to annual reduction in population, as pigs - to $7,66 \%$, sheep, goats - to $20,82 \%$ and horse $-23,52 \%$.

Look after the best situation in the poultry farming of Ukraine. This industry of stock-raising is vice versa marked with the annual gradual increase in bird population that testifies to development of this activity direction.

The estimation of production of stock-raising basic products types in Ukraine is presented in the table 3.

The most successful year for the meat production (all kinds in for slaughter weight) in Ukraine was 2013, the most subzero indexes of production are observed in 2010. In 2014 the production of meat exceeded the indexes of previous years by $14,60 \%$, that is the positive factor of industry development.

In the pattern of meat production in 2014 most part belongs to poultry meat - about $50,00 \%$, on the second place is a production of pork $-31,47 \%$, beef and veal $-17,49 \%$.

What touches the production of other types of stockraising foods evidently is that the production of wool and honey diminishes with every year. A production of milk in Ukraine is more or less stable for the last five years.

Technical and technological rearmament of every enterprise is the basic direction of efficiency increasing of the labour, land resources, complex mechanization and automation of technological processes, intensification of production using and on this basis increase in agricultural cultures productivity, animals productivity, volumes and quality of products, profitability and profitability of agricultural production (Bilyak, 2004).

One of basic factors that determine firmness of agriculture development is a level of it technical and technological providing. In Ukraine the level of the technical rigging of agriculture went down substantially (table 4).

From datasheet it is evidently that the amount of tractors in country agriculture in the period of 20102014 diminished by $13,55 \% \%$. And the same time such a situation is not only with tractors but also with all agricultural technique. Thus, only for this period the amount of combine harvesters grew short by $17,07 \%$,

Table 3

Production of stock-raising basic products types in Ukraine

\begin{tabular}{|l|c|c|c|c|c|c|}
\hline \multirow{2}{*}{ Types of products } & \multicolumn{5}{c|}{ Years } \\
\cline { 2 - 7 } & 2010 & 2011 & 2012 & 2013 & 2014 & 2014 in \% to 2014 \\
\hline $\begin{array}{l}\text { Meat of all kinds (in for slaughter } \\
\text { weight), thousands tones }\end{array}$ & 2059,0 & 2143,8 & 2209,6 & 2389,4 & 2359,6 & 114,60 \\
\hline Milk, thousands tones & 11248,5 & 11086,0 & 11377,6 & 11488,2 & 11132,8 & 98,97 \\
\hline Eggs, million points & 17052,3 & 18689,8 & 19110,5 & 19614,8 & 19587,3 & 114,87 \\
\hline Wool, t & 4192 & 3877 & 3724 & 3520 & 2602 & 62,07 \\
\hline Honey, t & 70873 & 70311 & 70134 & 73713 & 66521 & 93,86 \\
\hline
\end{tabular}

Source: from data of GST of Ukraine 
combines for corn - by $28,00 \%$, for potatoes - by $23,53 \% \%$, for beet - by $35,71 \%$, for linen - by $60,00 \%$.

Loading on one physical tractor and one combine substantially grew and exceeds normative indexes almost twice. The quality indexes of technical potential of country agriculture testify to the material and moral aging of technique. Majority of technique is purchased in 1991, the structure of tractor park is oriented to DT-75, MTZ-80, with an insignificant volume of more power-hungry machines.

In connection with annual quantitative composition reduction in car-tractor park and book value of agricultural enterprises, possibilities of the use of depreciation decrees for updating the fixed assets are diminished. In addition, only less insignificant part of these facilities heads for the technique purchase. Practically all sums go to addition to the turnover means in connection with their deficit.

Existent terms of budgetary support and leasing development, which determine the dynamics of active market part of the fixed assets, does not provide the proof updating of agriculture material and technical base. Experience of the machine-technological stations creation in Ukraine cannot be named as successful; in most cases economies form a car-tractor park independently. However a level of it using is not enough.

Analogical tendencies are characterize the dynamics of energy powers availability and consumption of electric power in country agriculture. Energy powers that is used in agriculture of country in 2014 comparatively to 2010 grow by $6,45 \%$. Mainly it takes place due to increasing power of electric motors in 2 times and equipments for the production of renewable energy - more than in 6 times. But power of engines of tractors, combines and selfpropelled machines and cars diminishes here. Also almost three times amount of draught animals diminished in a count on mechanical force.

Thus, the level of agricultural technique provision remains insufficient in number and quality, swingeing majority of technique is morally and physically threadbare, that results in the considerable overruns of labour and money.

Efficiency of agrarian production and competitiveness of products in internal and external markets depend also on the level of providing, use of labour resources and application of scientifically-reasonable management methods. A human factor - in optimal combination with natural, material and technical - is that initial link that forms basic motive force of becoming, development and effective management of all socio-economic modes in rural locality. At the same time development of several options in the conditions of market presents increase requirements to the man internals as carrier and personalized proprietor of labour force that is used in the process of consumer costs creation in form of commodities or services (Pokrovs'ka, 2014).

Table 4

Presence of agricultural technique in agriculture at the end of year

\begin{tabular}{|l|c|c|c|c|c|c|}
\hline \multirow{2}{*}{ Indexes } & \multicolumn{5}{c|}{ Years } \\
\cline { 2 - 7 } & 2010 & 2011 & 2012 & 2013 & 2014 & 2014 in \% to 2014 \\
\hline Tractors, thousand points & 151,3 & 147,1 & 150,1 & 146,0 & 130,8 & 86,45 \\
\hline $\begin{array}{l}\text { Power of engines of tractors, } \\
\text { thousand, kVt }\end{array}$ & 12557 & 12656 & 12942 & 12908 & 11826 & 94,18 \\
\hline Middle engine of tractor power, kVt & 83,0 & 86,0 & 85,9 & 88,4 & 90,4 & 108,92 \\
\hline Combine harvesters, thousand points & 32,8 & 32,1 & 32,0 & 30,0 & 27,2 & 82,93 \\
\hline Combine for corn, thousand points & 2,5 & 2,3 & 2,1 & 2,0 & 1,8 & 72,00 \\
\hline $\begin{array}{l}\text { Combine for potatoes, thousand } \\
\text { points }\end{array}$ & 1,7 & 1,7 & 1,6 & 1,5 & 1,3 & 76,47 \\
\hline Combine for beets, thousand points & 4,2 & 3,8 & 3,6 & 3,0 & 2,7 & 64,29 \\
\hline Combine for linen, thousand points & 0,5 & 0,4 & 0,3 & 0,3 & 0,2 & 40,00 \\
\hline $\begin{array}{l}\text { Options and aggregates for milking, } \\
\text { thousand points }\end{array}$ & 10,9 & 10,8 & 11,2 & 11,2 & 10,5 & 96,33 \\
\hline
\end{tabular}

Source: from data of GST of Ukraine

Table 5

Dynamics of quantity in capable of working rural population and middle salary in agriculture in Ukraine

\begin{tabular}{|l|c|c|c|c|c|c|}
\hline \multicolumn{1}{|c|}{ Indexes } & \multicolumn{5}{c|}{ Years } \\
\cline { 2 - 6 } & 2010 & 2011 & 2012 & 2013 & 2014 & 2014 in \% to 2014 \\
\hline $\begin{array}{l}\text { Amount of the employed population } \\
\text { in agriculture, hunt, forestry, } \\
\text { thousand persons }\end{array}$ & 3094,5 & 3393,8 & 3496,0 & 3577,5 & 3091,4 & 99,90 \\
\hline $\begin{array}{l}\text { Amount of the hired workers is in } \\
\text { agriculture, thousand persons }\end{array}$ & 647,3 & 633,7 & 623,9 & 582,2 & 526,7 & 81,37 \\
\hline $\begin{array}{l}\text { Average monthly nominal salary in } \\
\text { agriculture, hrn. }\end{array}$ & 1430 & 1791 & 2026 & 2270 & 2476 & 173,15 \\
\hline
\end{tabular}

Source: from data of GST of Ukraine 
In the present terms the question of agrarian producers providing by labour resources appeared actual enough in the context of system crisis and deepening of processes depopulation in a village, that stipulated worsening of quantitative and qualitative descriptions of skilled potential (table 5).

The analysis of table data testifies that amount of the concerned population in agriculture, hunt and forestry in Ukraine during 2010-2014 hesitates sharply. The greatest index presents 3577,5 thousand persons in 2013, that comparatively with 2010 is more by 483 thousand persons, or by $15,61 \%$. Thus in 2014 this index went down again to the level of 2010 and presented 3094,1 thousand persons. What touches the amount of the hired workers in agriculture is that this index annually has a tendency to decline and in 2014 it went down by 120,60 thousand persons, or by $18,63 \%$. Though an average monthly nominal salary in agriculture with every year increases, however it remains one of the least among other industries in the national economy of the country.

\section{Conclusions}

Thus, analysis of the modern state of resources provision in agrarian sector of economy in Ukraine is unsatisfactory and it gets worse every year. To overcome this problem agricultural commodity producers are unable be themselves. For an upturn in agrarian sector of economy in whole country and regional state, support of home agricultural producer, stimulation of his activity is needed. And first of all such measures in the agrarian sector of economy should become the self-weighted investment policy of the state, that will give an opportunity of bringing in of greater amount of investment resources for the improvement of technique at agricultural enterprises, development of production and sales co-operation, introduction of personnel management modern methodology, increase in labour activity level in agrarian sector, realization of the permanent updating and increase in quality of product control and others like that.

\section{References}

Bilyak, N.I. (2004). Estimation of the modern state of logistical support in agroindustrial complex. Zb. nauk. pr. LNAU, Luhans'k: LNAU, № 34/46, 34-38.

Kernasyuk, Yu. (2015). Where is Ukrainian agrarian expected. Ahrobiznes, №3 (298), 10-14.

Lupenko, Yu.O., Demyanenko, M.Ja, Kisil, M.I. etc. (2012). Strategic directions of investment support agricultural development in Ukraine till 2020. Kyiv: NNC IAE, 66.

Pokrovs'ka, O.V. (2014). Enterprise labour resources and the ways of their using efficiency increasing in agriculture. Retrieved from:http://repository.vsau.org/getfile/2819.pdf

Tatarenko, O.H. (2012). Investment constituent of agrarian sector of economy development. Investytsiyi: praktyka ta dosvid, № 5, 71-73.

Zorya, A., Zvyahina, K. (2015). That investments brought a harvest. Ahrobiznes, № 6 (301), 18-20.

\section{Ирина БЕЗПЬЯТА}

\section{АНАЛИЗ РЕСУРСНОГО ОБЕСПЕЧЕНИЯ АГРАРНОГО СЕКТОРА УКРАИНЫ}

Аннотация. Целью данной статьи является анализ уровня обеспеченности аграрного сектора экономики производственными ресурсами (земельными, трудовыми, техническое обеспечение), обеспечение которых обеспечивает эффективность хозяйственной деятельности и обоснование основных направлений рационального привлечения и использования ресурсного потенциала аграрного сектора экономики Украины в условиях рынка. Методика исследования заключается в использовании статистико-экономических методов исследования для анализа современного состояния использования производственных ресурсов в сельском хозяйстве за период с 2010 по 2014 года. Результаты исследования показывают, что ресурсное обеспечение развития аграрного сектора можно определить как совокупность определенных видов ресурсов (земельных, технологических, трудовых, финансовых) и источников их формирования, непосредственно участвующих в процессах развития аграрного сектора экономики, которые могут быть мобилизованы с целью обеспечения широкомасштабного использования их потенциальных возможностей и перехода сельского хозяйства к качественно новому состоянию. Анализ современного состояния обеспеченности ресурсами аграрного сектора экономики в Украине является неудовлетворительным и с каждым годом ухудшается. Преодолеть данную проблему в одиночку сельскохозяйственные товаропроизводители не в состоянии. Для улучшения экономического состояния аграрного сектора экономики страны необходима общая и региональная государственная поддержка отечественного сельскохозяйственного производителя, стимулирование его деятельности. И в первую очередь такими мерами должна стать взвешенная инвестиционная политика государства в аграрном секторе экономики, что позволит привлечения большего количества инвестиционных ресурсов для улучшения технического оснащения на сельскохозяйственных предприятиях, 
Vol. 2, No. 3, 2016

развитие кооперации производства и реализации продукции, внедрение современной методики управления персонала, повышение уровня трудовой активности в аграрном секторе, осуществление постоянного обновления и повышения контроля качества продукции и т.п. Практическое значение. Полученные результаты в процессе исследования могут быть использованы в практической деятельности сельскохозяйственных товаропроизводителей, органов управления на региональном и национальном уровне по повышению эффективности использования ресурсного потенциала аграрного сектора экономики. Значение/оригинальность. Результаты исследования позволяют определить основные направления для повышения эффективности использования ресурсного потенциала аграрного сектора экономики. Одним из условий внедренияэффективного, конкурентоспособного и высокопроизводительного сельскохозяйственного производства является инвестиционная деятельность, которая направлена на финансирование проектов и программ, связанных с развитием аграрного сектора экономики. Инвестиционная деятельность базируется на инвестиционной политике государства, четком законодательном поле, установленных приоритетах и направлениях и направлена на формирование действенного механизма управления инвестициями, создания экономически выгодных условий, которые стимулировали бы накопления капитала и эффективное его использование, учитывая реалии и специфику аграрного сектора экономики. 